\title{
THE EUROPEAN PRESENT AS WORLD HISTORY
}

\author{
GÖRAN THERBORN
}

Director of Swedish Collegium for Advanced Study in the Social Sciences. Uppsala (Sweden). ${ }^{1}$

\section{RESUMEN: El presente europeo como historia mundial}

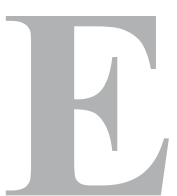

$\mathrm{n}$ el artículo se analiza la sociedad europea desde una perspectiva comparativa global, viéndola como parte de la historia mundial. Al mismo tiempo, se procura enfocar el presente como historia, es decir, relacionando la situación actual con el pasado $\mathrm{y}$, sobre todo, con el futuro. Se sitúa, entonces, a Europa en la historia de la Modernidad y en la dinámica de los diversos sistemas mundiales, a saber, el ecosistema planetario, el sistema poblacional, el del poder y la influencia, el sistema socio-económico y, finalmente, el cultural. Los futuros que se abren ante esa Europa oscilan entre una profundización de su relativa decadencia en términos mundiales y la búsqueda de una Segunda Modernidad.

\section{ABSTRACT}

The task of analyzing European society may be approached from many angles. The one chosen here is a global comparative perspective, an effort to step outside the tempting but myopic and often misleading familiarity of inside experience. Let us look at European society today as part of world history. What does it mean to grasp the present as history? It means to look out for how the current situation is related to the past, and, above all, to the future.

We shall here try to locate Europe in the history of modernity, and, secondly, in the dynamics of the world systems, systems in plural, as I shall explain later.

CORRESPONDENCIA:

Göran Therborn

Swedish Collegium for Advanced Study in the Social Sciences (SCAS).

Linneanum. Thunbergsvägen 2, S-752 38 Uppsala, Sweden.

Göran.Therborn@swedishcollegium.se

1 Seminario Internacional sobre Migraciones, Universidad de Alicante- CAM, 29 abril 2005. 


\section{THE EUROPEAN ROUTE TO MODERNITY AND TO POST- MODERNIZATION}

First a brief theoretical excursion, clarifying what is here meant by modernity, a controversial notion given several different meanings. The most fruitful definitions are the least arbitrary and idiosyncratic, which usually implies a respect for etymological meaning and an abstention from loading the definition with aprioristic connotations. Modernity should then be seen as a temporal orientation, only. Modernity is a culture claiming to be modern, in the sense of turning its back on the past -the old, the traditional, the passé-, and looking into the future as a reachable, novel horizon. Modern man/woman, society, civilization have a direction, forward. In order to keep its analytical edge, modernity should not be trivialized by attempts at translating it into concrete social forms.

Modernity established itself through social and cultural conflict, in ruptures with the past, breaking with ancient wisdom and customs. But these breaks took different expressions in different parts of the world, the traditional Others were different as well as the composition of the forces of the modern. The European road to modernity was unique in the sense that it was a road of civil war. The forces of modernity and the forces of tradition were internal to Europe, although colonial wars and colonial conquests crucially affected the intra-European struggles of the old and the new. The French Revolution, for instance, owed much to the weakening of the ancien régime from its series of world wars with Britain.

TABLE 1. Roads to/through Modernity by the Location of Forces and Cultures For and Against

\begin{tabular}{|c|c|c|c|}
\cline { 3 - 4 } \multicolumn{1}{c|}{} & \multicolumn{3}{c|}{ PRO-MODERNITY } \\
\cline { 3 - 4 } \multicolumn{1}{c|}{} & \multirow{2}{*}{ INTERNAL } & \multicolumn{2}{c|}{ EXTERNAL } \\
\cline { 3 - 4 } & & FORCED & IMPORTED AND LEARNT \\
\hline INTERNAL & Europe & Colonial zone & Reactive modernisation \\
\hline EXTERNAL & New Worlds of Settlement & \\
\hline
\end{tabular}

Note: Countries of Reactive, or externally induced, Modernisation, e.g., Japan, China, Ottoman Empire/Turkey, Iran, Siam/Thailand

The new future orientation of the last centuries first emerged in Europe, not as a natural emanation of European civilisation, but out of conflicts internal to Europe, to North-western Europe primarily. In other words, the European route was one of civil war, which pitted the forces of reason, enlightenment, nation/people, innovation, and change against those of the eternal truths of the Church, of the sublime wisdom and beauty of Ancient philosophy and art, of the divine rights of kings, of the ancient privileges of aristocracy, and of the customs of fathers and grandfathers.

In the New Worlds of European settlement, anti-modernity was, in the first rise of modern currents, perceived as mainly external, in the conservative metropolis, in Britain to North America, in Spain and Portugal to Latin America, and, increasingly, in the local Others of the settler societies, the natives, the 
slaves, and the ex-slaves. Independence got rid of the external metropolis, but what to do with the local Others was to haunt the moderns of the New Worlds for a very long time -still does-, particularly in Latin Indo-America, where the natives were not wholly or virtually exterminated.

To the Colonial Zone, from North-western Africa to Southeast Asia, modernity arrived literally out of the barrel of guns, with the colonial conquest, subduing the internal forces of tradition. Modernity was not carried further by settlers, but by new generations of natives, of "évolués" who turned what they had learnt from their conquerors against the latter. After Independence the ex-Colonial Zone has carried a complex legacy of nationalism, a colonial elite culture -of language, habitus, and, e.g., exotic sports interests (like cricket in South Asia and the Anglo-Caribbean)- and colonial-turned-excolonial statesociety bifurcation.

The countries of Reactive Modernisation were challenged and threatened by colonial domination, and in the face of these threats a part of the internal elite started to import innovation from the outside, creating special combinations of modernism and traditional authority. Japan is the most successful and clear-cut example.

The European civil war between the forces of modernity and those of tradition was a protracted struggle over centuries, starting in science in early $17^{\text {th }}$ century, including many defeats of the modern, and politically definitely won in Spain only in the 1970s, with the end of the Franco regime. But the question here, this afternoon, is where is European modernity today? In order to at a provisional answer, we had better specify modernity into a set of "master narratives" or guiding lines of modernist argumentation. There are, at least, five such main discursive themes of modernity.

\section{TABLE 2. Master Narratives of Modernity}

\begin{tabular}{|l|l|}
\hline THE PAST WAS/THE PRESENT IS & \multicolumn{1}{|c|}{ THE FUTURE WILL BE } \\
\hline 1. Ignorance, superstition, subservience to authority & Emancipation, individual: rational, empirical \\
2. Oppression, exploitation & Emancipation/liberation, collective: socio-political \\
3. Poverty, disease, stagnation & Growth, progress, development \\
4. Conditions of no/less competition & Survival of the fittest, more relative power \\
5. Rule-bound, imitative & Creative vitality \\
\hline
\end{tabular}

Has the very triumph of modernity made these modernist contrasts and futures irrelevant? That is the challenge of post-modernism. The answer, I think, has to be specified according to narrative, political perspective, and world region. Let us make a rapid overview of Europe in these respects.

The first modernist argument, of individual emancipation by the use of reason the senses of observation, was summed up in the Enlightenment, and in Kant's definition of it. The victory of science and the secularization of society in the recent decades have made enlightenment a rather banal part of European everyday present life. Counter-assertions of divine authority have become 
marginal, even in post-Communist Europe. So-called New Age attempts at re-enchanting the world appear both superficial and marginal.

Collective emancipation has become focused on gender and sex, on the liberation of women from gender oppression and discrimination and of homosexuals from sexual ditto. The emancipation of the industrial workingclass has run as far as it could get, in the 970s-early 1980s, and no emancipatory project of the post-industrial classes, employed and unemployed, has caught on yet. Emancipation from ethnic discrimination, an increasingly important theme on the European left, remains a minority striving as long as it is not integrated into an emancipation from the nation-state into some post-national, multicultural polity.

Growth and development, economic modernization in this sense, constitute a leitmotif of the European political, as well as economic, elites. In particular, this theme has become the banner of the neoliberal right, but also by a neoliberal centre-left, most significantly expressed by Tony Blair and Blairism. Eastern Europe, historically the late modern part of the continent, is engaged in a largescale modernist project of catching up development and growth. But, what about Western Europe? It seems that economic progress has little of non-elite appeal outside a rather small stratum of young centre-right prospective careerclimbers. Sustained growth may be needed to vouchsafe pension obligations, but it is no longer part of a popular vision of a new, higher standard of living. The political development of Europe, as "an ever closer union" among its peoples was always mainly an elite project -in spite of its success- and is currently even more so.

The fourth modernist story, of new struggles for survival, was that of Social Darwinism and later of Fascism. It has recently returned in the neoliberal vision of globalization, with its new demands of competitive effort. But globalist Social Darwinism is little more than a delimited managerial ideology. The main popular response to globalist challenges has rather been conservative, defending existing social rights of workers and of citizens.

Finally, the disappearance of rule-bound aesthetic academicism has left modernism without an aesthetic target. No wonder, then, that the modernist drive to constant innovation produced postmodernism in the arts and in architecture, and no wonder that in those fields the moment of postmoderism has already become passé.

To conclude, the very success of Western European modernity has sapped its energy and thrust. Economically, a serene prosperity makes good sense. But the post-modernization of Europe is uneven not only between east and west. It is also upsetting European politics. Historically, the European left-right division was, by and large, with some exceptions, a division between leftwing modernism and rightwing traditionalism. What is currently happening is a post-modernization of the left and a modernization of the right. This creates a new political landscape, quite bewildering to many, particularly, but not only, to the historical popular electorate of the left.

One of the increasingly clear differences between Western Europe and the United States is that the latter spawns a much broader based rightwing politico- 
economic modernism, believing in its capacity as well as in its right to create a new future. In a currently hegemonic coalition, this rightwing modernism is politically beefed up by militants of religious fundamentalism. On the world arena, the post-modernization and self-doubt of the distinctive European political traditions, of Social Democracy, popular Christian Democracy, Eurocommunism, and Social Liberalism, mean a weakening of Europe in relation to the USA.

Western Europe generated the pioneers of the current world epoch of modernity, who came to upset the balance of the whole world. Today, Western Europe, perhaps together with Japan, is the site of an uneven postmodernization, which tends to contribute to a new tilt of the world, to the United States, at least in the short run.

But after this situating of Europe in the time of modernity, we should try to locate it in the spatial dynamics of world systems.

\section{THE WORLD SYSTEMS AND EUROPE WITHIN THEM}

What is currently referred to as "globalization" is a multidimensional phenomenon of world-wide interaction and interrelations. In order to get at this multidimensionality, we may distinguish five major planetary systems of humankind, in which Europe is located, and being challenged. Talking about systems in plural is meant to convey their irreducibly possible differences, their analytical distinguishability, but not their inter-connexions and interdependencies.

The order of presentation is basically arbitrary. The one chosen here runs from the most natural to the most cultural without, it should be underlined, any particular assumptions of relative causal efficacy.

\subsection{With that contingent logic of presentation we should start with a few words about the planetary ecosystem.}

Europe is luckily located in this system, with sufficient water resources, and outside or at the margin of planetary disasters, like earthquakes, tsunamis, and high-disease-producing climates, like the tropics. But European ecology is also a historical product of European social action. Europe was a historical pioneer of public hygiene and health. Malaria occurred in the $18^{\text {th }}$ century even in the south of England, for instance, but was eliminated long ago. HIV-AIDS was first mainly a North American disease, before it became African in the 1990s. In Europe it has been relatively marginal.

On the whole, its high ecological quality of life, with less natural risk, less pollution, less urban slumming, and less violence, has become a distinctive feature of early $21^{\text {st }}$ century Europe. A worldwide composite environmental sustainability index is topped by four European countries and Canada, while the Ukraine and Belgium come quite low. An urban quality of life index has 8 European cities, headed by Zurich and Geneva, among the eleven on top of the world, whereas another ranking of healthy cities puts Canadian Calgary and 
Ottawa, and Honolulu before most European cities, among which Helsinki, Oslo and Stockholm stand out.

\subsection{A second world system is humanity as a population system:}

Demographically, the weight of Europe is going down, from a quarter of world population in 1900 to an eighth in 2000, and projected to harbour only a fifteenth in 2050. Germans, Italians, Russians and many other Eastern Europeans have already begun dying out, with deaths exceeding births. Europe is also ageing, possibly having almost one third of its population 65 years of age or older by 2050. Ageing and probable population decline are setting Europe and Japan off from USA, the only rich country still reproducing itself naturally.

20th century experience tells us, though, that birth rates are hardly governed by some iron law of "demographic transition", and may go up as well as down. A comparison of surveyed desires of children, on one hand, and actual birth rates, on the other, shows that there is currently a Western European birth deficit of about $0.7-0.8$ child per woman. That is, European women are currently bearing fewer children than they would like to -under ideal conditions of work, housing, and adequate partner supply-.

For almost five centuries, Europe was a continent of out-migration, exporting its adventurers, its dissidents, and its poor surplus population to other parts of the world. Particularly in the decades just for and after 1900, this was a very important, very privileged position in the population system of humankind. Since the 1960s, Europe as whole, but actually Western Europe, has become a continent of immigration. For Europeans, this should be a source of pride. It testifies to the success of post-colonial Europe, that it has become a pole of world attraction. The change has been dramatic, most recently in Southern Europe, which had the longest history of emigration, but also in other parts of Europe. Traditionally ethnically very homogenous Sweden, for example, has currently as large a proportion of its population foreign born the United States, officially at least. That is, about one eighth of its population.

A major challenge to Europe is whether it will be as successful in incorporating the new Europeans as USA has been in its reception of new Americans. So far, this is hardly the case.

\subsection{The system of power and influence: Here we should take three key va- riables into account, military power, civilian power and influence}

The military decline of Europe was demonstrated in World War II, and clear to all by the time of the Suez fiasco. Efforts to undo it are most unlikely to succeed. Global political hegemony was lost by military defeats, wartime economic devastation and by the end of European colonial empires. In the post-WWII configuration of "the West", Europe has always been the junior, the dispensable partner to the "indispensable nation", as Clinton's Secretary of State called the United States. European world supremacy will hardly return. If military power in the world will become multipolar again, the balance to the US superpower will come from China and India. 
Civilian power may take several forms. Economic clout and muscle is clearly one and important. The EU is without doubt a major economic power in the world, and we shall return to it below. But civilian power is also constituted legal authority. It is the non-military power of sovereign states and the power of international law.

Let me first say a few words about the power of nation-states in the current era of globalization. What is often forgotten is that the last decades of the $20^{\text {th }}$ century saw an enormous expansion of the state. In the OECD countries -i.e.,Western Europe, North America, Oceania and Japan-, public expenditure as a proportion of GDP increased on the population-weighted average by 19 percentage points between 1960 and 2000. This growth of the state is most pronounced in Western Europe, where general government outlays made up almost half (49\%) of the GDP of Euroland in 2004. The civilian power of the national European welfare states is substantial, and much bigger than fifty or a hundred years ago.

In a context of migration studies it should be added, that state control of international migration is tighter today than a century ago.

Europe is of old the world's lawyer, the source, the pioneer and the vanguard of international law. The political process of European integration has above all else been the constitution of Europe as a normative area of transnational law.

The Council of Europe adopted in 1950 the first international, legally binding convention on human rights, enforced by a Commission, a Committee of Ministers with a majority voting system and a Court. It was concerned with civil and political rights only, and it took more than a decade for its supranationality to be fully recognized by all member states, but it did take effect. In 1961 an extensive European Social Charter was adopted, formulated as obligations accepted by the member states, with a supra-national monitoring and complaint system, in the last instance issuing into recommendations of the Ministerial Committee with two thirds majority.

The European Court of Justice, with support from the national judiciaries of the EEC/EU member states, has constituted a major supra-national force in the construction of a new Europe. In a couple of early landmark decisions, in 1963, 1964 and in 1970, the Court established the principles of direct effect of Community law, and of its supremacy over national law, including, within its area of jurisdiction, over national constitutional law. In the Internationale Handelsgesellschaft case of 1970 the Court stated, that "the validity of a Community measure (...) cannot be affected by allegations that it runs counter to (...) fundamental rights as formulated by the constitution of that state...".

It is only in Europe that a transnational legal power has been established. But the EU and its member states are the main force behind global initiatives and support of attempts at international law and normative regulation, from the UN Conventions to the International Criminal Court and the Kyoto Protocol.

A system of power also includes more diffuse processes of influence, whether by persuasion or by inspiration. The European system of a number of more or less equal sovereign states gave rise to diplomacy as a profession. 
In today's world politics, the European skills of and preference for diplomacy differ from the more blunt, threatening and violent policies of the United States. The latter not seldom see to it that European civilian diplomacy is overtaken by military action, as in Bosnia, Kossovo and Iraq. European diplomatic influence is kept in tight reins by the Americans.

Influence may further take the form of inspiration of providing models of action to other actors. The union of Europe has become an important source of inspiration, and even a model of partial imitation, in Southeast Asia, in Latin America, and most recently in Africa. In spite of all attention to globalization, world trade has also become more regionalized in the past decades.

In some other areas, Europe may have lost world influence to USA. The decline of French cultural influence in the world, for instance in Egypt, Iran and in Latin America, has been picked up by US influence. But influence is not always dependent on power, as the widespread international interest in the policies of and institutions of little Scandinavia, and of Sweden in particular demonstrates. A future Europe as the world's Scandinavia would be a position of influence without power. It is hardly a bad scenario.

2.4. The socio-economic system, of the global division of labour, social structuration and market exchange is mainly what Immanuel Wallerstein has in mind when he talks about the world system

In our list here it is the fourth system. It is a broader conceptualization than the world market or the world economy, as it also pays systematic attention to social structuration.

Europe is the world's major trader and as such the centre of world market exchange. In 2000 a good fourth of all global foreign trade, 27 per cent, took place within Western Europe, almost a third (29 per cent) within all Europe and forty per cent of world exports originated in the countries of Western Europe. US exports, including commercial services, amounted to fourteen per cent of the world total and Japanese to seven Euroland is also running a large surplus on its current account, while US exports are increasingly unable to pay for the country's imports, in spite of the continuing innovation dynamics of American capitalism.

In 2000, Western Europe owned more than half of the world's stock of foreign direct investment, 57 per cent, while the US owned a fifth and Japanese investors barely five per cent (4.7\%). Western Europe is also the largest host of foreign investment, holding almost forty per cent of the world stock in 2000, while USA harbours twenty per cent and Japan less than one per cent. In flow terms, the countries of Western Europe sent out more than two thirds (71\%) of global foreign direct investment in 2000 and received half of it. US firms accounted for only one eighth of the outward flow of foreign direct investment.

The EU25 is now the world's biggest economy, with a GDP 25\% larger than that of the United States, although this is an effect of political aggregation and not of superior economic performance. In terms of relative prosperity, the USEurope relation is reversed. Luxemburg apart, only Norway has a purchasing 
power per capita on par with USA, in fact slightly superior, while France and Germany stay at $75 \%$ of the American level, Euroland slightly below that, and the EU as a whole still further from American affluence.

In sum, while no longer the richest part of the earth and no longer the prime economic model of the world, Western Europe is the central node of global flows of trade and of capital, their main mover. European integration has now given this world trade centre a base in the largest economy of the globe. Trade policy and the WTO are the only policy area and global institution, respectively, where the EU is standing up to the US.

Historically, Europe was both the global centre of industrial production and the only industrial society of the world, where industrial employment ever came to dominate post-agrarian society. Industrial social polarization and the European route to modernity through internal conflict made class, class consciousness, class organization and class conflict more clear, explicit and more comprehensive than in other parts of the world. Europe was the world centre of the labour movement. De-industrialization, which stated in the late 1960s, -in Eastern Europe after 1989- has been a dramatic change of Europe.

The post-industrial legacy of industrial class struggle and class pressure is that Europe today is the least inegalitarian part of the world. In Britain Thatcherism managed to undo a large part of the secular gains of the popular classes, as did most capitalist restorations in Eastern Europe. Nevertheless, Northern and Central Europe, east of Britain and west of Poland and of Carpathian Ukraine stands out as the global centre of what economic equality there is in this world.

TABLE 3. The Least Unequal Countries of the World, and Comparisons with Some Other Outcomes. Disposable income after taxes and transfers

\begin{tabular}{|l|c|}
\hline ROUTE & AVERAGE GINI COEFFICIENT CIRCA 2000 \\
\hline Scandinavian Social Democracy & 25 \\
Particular Communist Legacy & 25 \\
Western European Christian and Social Democracy & 26 \\
Northeast Asian National Capitalism & 32 \\
\hline
\end{tabular}

\begin{tabular}{|l|c|}
\hline OTHER OUTCOMES & AVERAGE GINI COEFFICIENT CIRCA 2000 \\
\hline Spain (1990) & 30 \\
USA & 37 \\
Russia & 43 \\
China & 45 \\
India & $(33)^{*}$ \\
Mexico & 49 \\
Brazil & 64 \\
Nigeria & 51 \\
\hline
\end{tabular}

* Distribution of consumption expenditure, always more equally distributed than income. Scandinavian Social Democracy: Denmark, Finland, Norway and Sweden. Particular Communist Legacy: Belarus, Czech Republic, Slovakia and Slovenia. Western Europe: Austria, Belgium, Germany and Netherlands. Northeast Asia: Japan, South Korea and Taiwan.

It is noteworthy that Europe, and Northwestern Europe in particular, has been able to combine being the world's central trader and transnational investor 
with achieving the least inequality in the world. In the 1990s, the distribution gap between this part of Europe and the rest of world increased substantially. Equality and trading are distinctive features of European society, likely to remain.

\subsection{Finally, the world is a system of culture}

It has four core elements: first, an architecture of identities, of self-and other identifications of major social groups. Second, a geocultural pattern of values and norms. Thirdly, a structure of cognition, of the production and diffusion of knowledge. And fourthly, configurations of symbolic forms. The latter include language patterns, "high" culture of the arts and popular or mass culture, of entertainment, life-styles and commercial brands. The culture system is sustained by a pattern of communications.

The European location in this complex, still under-researched system might be summed up in terms of, disputed and uncertain identity, characteristic values of secularism and postnationalism, cognitive demotion from leading centre to mainly second station, centrality of high culture but at best seconds in popular culture.

On a global scale, European identity has a got a shadowy existence, as a secondary part of a US-dominated "West". Inside Europe, on the other hand, the rise of the EU and the end of the Cold War, have contributed positively to a European identity, but far from comparable in significance to national identities, which, by the way, first emerged in Europe.

Historically, Western Europe was a totalitarian cultural area of the world, in principle mono-religious and mono-lingual. Jews and Muslims were expelled, and the prince decided which version of Christianity should prevail, according to the formula of the Westphalian Peace Treaty: cuius regio, eius religio. With the Enlightenment began a gradual retreat from zero tolerance in matters of religion. But then came the $19^{\text {th }}$ century/early $20^{\text {th }}$ century nationalist drive for one nation, one language.

Eastern Europe, particularly the stretch from the Baltic Poland-Lithuania to the Ottoman Balkans, was by contrast the pluralistic and tolerant part of Europe, if often also arbitrary and unpredictable. Eastern nationalism of from late $19^{\text {th }}$ century till 1950 and re-asserted again in the break-up of Yugoslavia in the 1990s ended brutally that history of multi-ethnic multiculturalism.

The new mass immigration into Western Europe means then a tremendous challenge to the identity of Europeans. France, the only European country of long immigration experience, has been relatively successful in incorporating immigrants into national identity, but even there actual socio-economic exclusion indicates increasing limitations. Most other Western European states have a much less absorbing national culture than the French, while hardly being more capable of accepting and developing a multi-ethnic national identity. The issues of multi-ethnic and multi-cultural identities had better be approached on the European than on the national level, as part constructing a new, overarching European identity. A new European identity, not rooted in European history 
and traditions, but built from European lessons from, and break with European and world history.

In value terms, Europe has become the most secularized and rationalistic part of the world and also the least nationalistic or communalistic. Postreligiousness and post-nationalism have become the most distinctive of European values. However, these are markers of a relative void. It is much less clear if there are any characteristic positive European values and what they are in that case. Possibly, egalitarianism and a solidaristic individualism -values embodied in the European welfare states, particularly in their northwestern variant- could be candidates, together with a universalistic conception of human rights. Together with North America, Europe is also the centre of the post-patriarchal world, where enduring gender inequality remains after the demise of the laws of fathers and husbands.

In scientific knowledge production, Europe lost its leading position to USA, thanks to Fascism and to the outcome of WWII. Out of 371 Nobel laureates in science and economics for 1946-2000, 218 or 59\% were based at institutions in the United States, and 139, or 37 percent in Western Europe. Fourteen laureates, four cent worked in the rest of the world. In what is more a broad base measure, entries in the science citation index, USA and the EU15 were even in 1996-2000, each producing 39 per cent of the citations. Japan got 6 per cent, Latin America and South Asia one per cent each (to what extent these prizes and citations reflect cognitive achievement only, and to what extent they also reflect patterns of intellectual power and of attention is a question which cannot answered here).

The competitive resources of US elite institutions make a EU-US redress unlikely, although the vast field of science leaves many frontiers open to European initiatives. In the humanities and in social theory, there is still distinctive European scholarship among the global avant-garde. But they are in need of globalist infusions to overcome still considerable Eurocentric and/or national myopia.

With respect to symbolic forms, Europe rather long ago lost its edge in international mass culture to the US -jazz, Hollywood- to which television and commercial market brands have added more recently. Of the 100 most valuable commercial brands in the world, 63 are American, including 8 of the top ten, and 29 are Western European. But global mass culture has also important regional centres. Britain is clearly one of them, while the East and South Asian ones are clearly of mounting importance.

In terms of "high culture", or high art, Europe is still the world centre of literature, of music, probably again of painting -after the end of NewYork Abstract Expressionism-, as it is in the world of luxury fashion. Documenta in German Kassel is the meeting-place the avant-garde art of the world. Together, Paris, London, and Milan are the leading global cities of high culture. Cultural leadership is always open to contestation though.

The electronic technology carrying the bulk of the current cultural system was largely developed in USA, personal computers, satellite broadcasting, the internet. But the basic technology is now in the global public domain, and now 
driven by several major players. Europe has been particularly successful with respect to mobile telephony, Nokia, Ericsson. The future of communications technology and of its implications for the world system of culture seems to be completely open.

\section{TO CONCLUDE}

In a longterm historical perspective, Europe is a continent in relative decline, militarily and demographically, and as a world producer. The very success of its modernity and the social trauma of de-industrialization of the world's most industrial continent have led to a wide-spread post-modernization and political uncertainty among almost all the main political families of $20^{\text {th }}$ century Europe. European cultural hegemony was a $19^{\text {th }}$ century phenomenon and began to erode by the end of World War I.

That means, in my opinion, that conventional big power dreams, still repeated aloud by political leaders of the former big powers o Europe, are futile.

On the other hand, the contemptuous anti-Europeanism which sees current Europe as on its way to becoming little more than a museum is completely wrong. Europe is the hub of transnational economic flows and the largest if not the most affluent integrated economy. It is the vanguard of transnational politics and transnational law and as such a worldwide source of inspiration. It is an ecologically privileged and well-constructed part of the world, capable of offering an extraordinary quality of life for ordinary people, and a centre of the arts, and if no longer leading it is still a major producer of world scientific knowledge.

The dynamic potential of this European position in the world may taper off, in political and social confusion and division. Bad omens are visible, in the handling of the constitution and of the enlargement of the EU. But it may also be released, by a Second Modernity, a project of transnational, multiethnic, multicultural and egalitarian development. 